\title{
TTF salts of optically pure cobalt pyridine amidates; detection of soluble assemblies with stoichiometry corresponding to the solid state
}

\author{
Nikola Paul Chmel ${ }^{\mathrm{a}}$, Laura E. N. Allan ${ }^{\mathrm{a}}$, Jan M. Becker ${ }^{\mathrm{a}}$, Guy J. Clarkson ${ }^{\mathrm{a}}$, Scott S. Turner*b ${ }^{*}$ and Peter Scott ${ }^{* a}$ \\ Received (in XXX, XXX) Xth XXXXXXXXX 200X, Accepted Xth XXXXXXXXX 200X \\ First published on the web Xth $X X X X X X X X X 200 X$ \\ DOI: $10.1039 /$ b000000x
}

Optically pure anionic complexes of pyridinecarboxamide ligands, $N^{2}, N^{6}$-bis $((R)-\alpha-$ methylbenzyl)pyridine-2, 6-dicarboxamide $\mathrm{H}_{2}\left(R, R-\mathrm{L}^{1}\right)$ and $N^{2}, N^{6}$-bis((S)-1-methoxypropan-2yl)pyridine-2, 6-dicarboxamide $\mathrm{H}_{2}\left(S, S-L^{2}\right)$ have been synthesised and fully characterised. The 10 complexes: (18-crown-6)K[Co"' $\left.\left(R, R-\mathrm{L}^{1}\right)_{2}\right],\left(18\right.$-crown-6)K[Fe $\left.{ }^{\prime \prime \prime}\left(R, R-\mathrm{L}^{1}\right)_{2}\right]$ and $\mathrm{K}\left[\mathrm{Co}^{\prime \prime \prime}\left(S, S-\mathrm{L}^{2}\right)_{2}\right] \cdot 3 \mathrm{H}_{2} \mathrm{O}$ show interesting extended structures from $0 D$ discrete units through $1 \mathrm{D}$ zigzag chains to $2 \mathrm{D}$ honeycomb layers. The complex anions were used in the synthesis of radical cation salts with tetrathiafulvalene (TTF). The salts (TTF) $\left[\mathrm{Co}^{\prime \prime \prime}\left(R, R-\mathrm{L}^{1}\right)_{2}\right]$ and (TTF) $\left[\mathrm{Co}^{\prime \prime \prime}\left(S, S-\mathrm{L}^{2}\right)_{2}\right] \cdot$ EtOAc were characterised by single crystal $\mathrm{X}$-ray diffraction and conductivity measurements. Both compounds

15 comprise mono-oxidised TTF molecules and exhibit similar layered structures with no direct TTF stacking but in which phenyl substituents from the complex anion or co-crystallised ethyl acetate alternate with $\mathrm{TTF}^{+}$units. Solution spectroscopic and cyclic voltammetric evidence points to the formation of soluble assemblies between $\mathrm{TTF}^{+}$and the counterion which correspond to the stoichiometry observed by crystallography and other methods in the solid state.

\section{${ }_{20}$ Introduction}

Interest in the synthesis of chiral molecular conductors has been recently ignited by the discovery of Magnetic Chiral Anisotropy (MCA). ${ }^{1-2}$ Rikken predicted that the resistance of the chiral conductor will depend both on the external 25 magnetic field and the current and its handedness, thus giving rise to the possibility of using this type of material as magneto chiral switches, or in the field of spintronics. ${ }^{1}$ Our efforts in this field focus on charge transfer salts, based on organic achiral donors such as tetrathiafulvalene (TTF), with 30 optically pure anions. Hence we are engaged in developing synthetic routes to the latter. ${ }^{3}$ An alternative approach, the use of chiral donor molecules, generally results only in poorly conductive materials. ${ }^{4}$

In stark contrast to optically pure chiral cations, ${ }^{5-11}$ only a 35 few families of optically pure complex anions are known. This is most likely due to the scarcity of anionic complexes in general and the difficulty of diastereoselective synthesis or resolution. ${ }^{12-13}$ In our search for viable building blocks for the construction of optically pure conducting materials we came

40 across few families of anionic octahedral complexes with tridentate chiral ligands. ${ }^{14-15} C_{2}$ symmetric species have especially attracted our attention, since these would preclude the formation of the additional chiral centre in the coordination complex, thus removing the problem with 45 diastereoselectivity control on the new chiral centre.

A family of $\mathrm{C}_{2}$ symmetric tridentate
pyridinedicarboxyamide ligands have been developed. ${ }^{16-19}$ These ligands have shown ability to stabilise the trivalent oxidation state of the transition metals, due to the presence 50 of deprotonated organic amide groups. ${ }^{20}$ Recently, ligands from this family have been shown to form bimetallic complexes which have been tested for catalytic activity. ${ }^{21}$
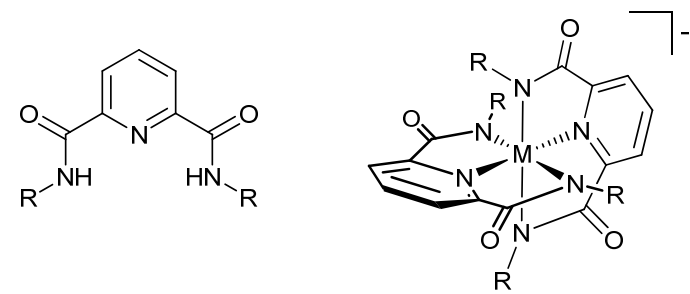

Fig. 1 Structure of a pyridinedicarboxyamido ligand and its metal complex.

This family of $\left[\mathrm{M}^{\prime \prime \prime}\left(\mathrm{L}^{\mathrm{n}}\right)_{2}\right]^{-}$( $\left.\mathrm{M}=\mathrm{Co}, \mathrm{Fe}\right)$ complexes has been chosen due to its relatively easy accessibility and the wide range of modifications possible. This paper focuses on the synthesis of such anions and their charge transfer salts with 60 tetrathiafulvalene (TTF), as well as on determination of the relations between the electro- and spectrochemical properties of the solution to the stoichiometry and properties of the solid state material.

\section{Results and discussion}

${ }_{65}$ Ligands and complex anions synthesis

The parent chiral ligand in this study is the $N^{2}, N^{6}-b i s((R)-\alpha-$ methylbenzyl)pyridine-2,6-dicarboxyamide $\mathrm{H}_{2}\left(R, R-\mathrm{L}^{1}\right)$ (Scheme 1). It is formed in a high yield in the reaction of the appropriate amine with pyridine-2,6-dicabonyl dichloride in ${ }_{70}$ DCM in the presence of TEA. The chloride can be synthesised in situ by a reflux of pyridine-2,6-dicarboxylic acid with thionyl chloride in DCM. It was however observed that higher yields are obtained if the chloride is isolated and additionally purified by distillation at high vacuum. The purified 75 compound can be stored for a period of a few weeks without 
decomposition.

Metal complexes were obtained using the synthetic strategy adapted from the literature. ${ }^{20}$ Deprotonation of the ligand with potassium hydride in dry THF gives the potassium 5 salt $\mathrm{K}_{2} \mathrm{~L}^{\mathrm{n}}$ which on reaction with anhydrous cobalt(II) or iron(II) chloride under Schlenk conditions yields the dianionic metal(II) complexes. In situ oxidation in air gives the desired complexes (Scheme 1).
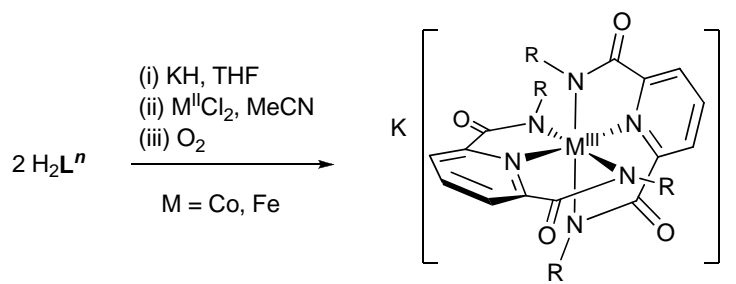<smiles>C[C@H](NC(=O)c1cccc(C(=O)N[C@H](C)c2ccccc2)n1)c1ccccc1</smiles><smiles>COC[C@H](C)NC(=O)c1cccc(C(=O)N[C@@H](C)COC)n1</smiles>

Scheme 1 Reaction scheme of synthesis of pyridine amide complexes

The use of the 18-crown- 6 improves the solubility of the complexes in organic solvents. Resulting (18-crown6) $\mathrm{K}\left[\mathrm{Co}^{\prime \prime \prime}\left(R, R-\mathrm{L}^{1}\right)_{2}\right](\mathbf{1 a})$ and (18-crown-6) $\left[\mathrm{Fe}^{\prime \prime \prime}\left(R, R-\mathrm{L}^{1}\right)_{2}\right](2)$ are readily crystallised and were fully characterised. The crystal 15 structure of the complex $\mathrm{K}\left[\mathrm{Co}^{\prime \prime \prime}\left(R, R-\mathrm{L}^{1}\right)_{2}\right] \cdot \mathrm{MeOH}$ (1b) analogous to 1a without the crown ether was also obtained.

Analogous treatment of ligand $\mathrm{H}_{2}\left(S, S-L^{2}\right)$ gave $K\left[\mathrm{Co}^{\prime \prime \prime}(S, S\right.$ $\left.\left.L^{2}\right)_{2}\right] \cdot 3 \mathrm{H}_{2} \mathrm{O}(3)$. The use of crown ether was not necessary, as the complex exhibits excellent solubility in acetonitrile and 20 other organic solvents. The compound was characterised by NMR, mass spectrometry, microanalysis and single crystal $X$ ray diffractometry.

\section{Optical purity}

The optical purity of the ligands was assesed and in particular 25 the possibility of epimerisation during the amide deprotonation step was excluded as follows. A small sample of the apparently optically pure $R, R$-ligand was treated with $\mathrm{KH}$ in $d^{8}$-THF for $12 \mathrm{~h}$ to deprotonate the amide groups, after which the ${ }^{1} \mathrm{H}$ NMR spectrum was recorded. The sample was 30 then carefully hydrolysed with distilled water. ${ }^{1} \mathrm{H}$ NMR spectroscopy gave no indications of the presence of a second diastereomer $(R, S)$ as would be expected in the case of epimerisation at the proximate $\mathrm{CH}$ group. The solvent was removed from this sample and the residue was redissolved in

35 acetonitrile for measurement of the optical rotation. This was found to be $=-220^{\circ}$ the same as the optically pure sample measured previously.

Crystal structures of $\left[\mathrm{Co}^{\prime \prime \prime \prime}\left(\mathrm{R}, \mathrm{R}-\mathrm{L}^{\mathrm{n}}\right)_{2}\right]^{-}$complexes (18-crown-6)K[Co' $\left.\left(\mathrm{R}, \mathrm{R}-\mathrm{L}^{1}\right)_{2}\right] \cdot \mathrm{H}_{2} \mathrm{O} \cdot \mathrm{MeCN}\left(1 \mathrm{a} \cdot \mathrm{H}_{2} \mathrm{O} \cdot \mathrm{MeCN}\right)$
40 Details of the structure solution and refinement for $1 \mathrm{a} \cdot \mathrm{H}_{2} \mathrm{O} \cdot \mathrm{MeCN}$ can be found in Table 1 . The compound crystallises in a chiral monoclinic space group $\mathrm{P} 2_{1}$.

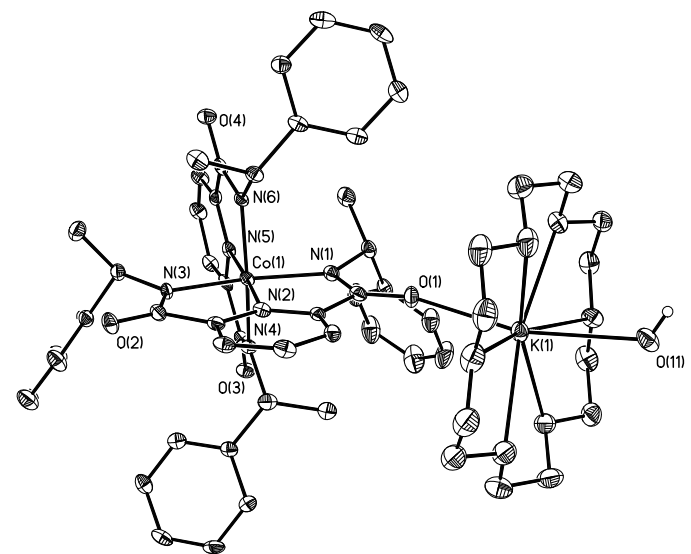

Fig. 2 Solid state structure of $\left(18\right.$-crown-6) $\mathrm{K}\left[\mathrm{Co}^{\mathrm{III}}\left(R, R-\mathrm{L}^{1}\right)_{2}\right] \cdot \mathrm{H}_{2} \mathrm{O} \cdot \mathrm{MeCN}$ 45 (1a) with thermal ellipsoids at $50 \%$ probability. Most hydrogen atoms, and $\mathrm{CH}_{3} \mathrm{CN}$ of crystallisation have been omitted for clarity. Selected bond lengths $(\AA)$ and angles $\left({ }^{\circ}\right)$ : $\mathrm{Co}(1)-\mathrm{N}(1) 2.017(2), \mathrm{Co}(1)-\mathrm{N}(2) 1.862(2)$, $\mathrm{Co}(1)-\mathrm{N}(3)$ 1.994(2), Co(1)-N(4) 1.972(2), Co(1)-N(5) 1.853(2), Co(1)$\mathrm{N}(6) 1.960(2), \mathrm{K}(1)-\mathrm{O}(1) 2.691(2), \mathrm{K}(1)-\mathrm{O}(11)$ 2.882(3), N(5)-Co(1)$50 \quad \mathrm{~N}(2)$ 176.25(10), N(5)-Co(1)-N(6) 81.94(9), N(5)-Co(1)-N(4) 81.90(9), $\mathrm{N}(6)-\mathrm{Co}(1)-\mathrm{N}(4)$ 163.80(8), N(2)-Co(1)-N(3) 81.80(9), N(4)-Co(1)-N(3) 92.73(9), N(2)-Co(1)-N(1) 81.74(9), N(3)-Co(1)-N(1) 163.43(8). Angle between mean planes of diamidopyridine units of the ligands: $84.1^{\circ}$.

55

a

b
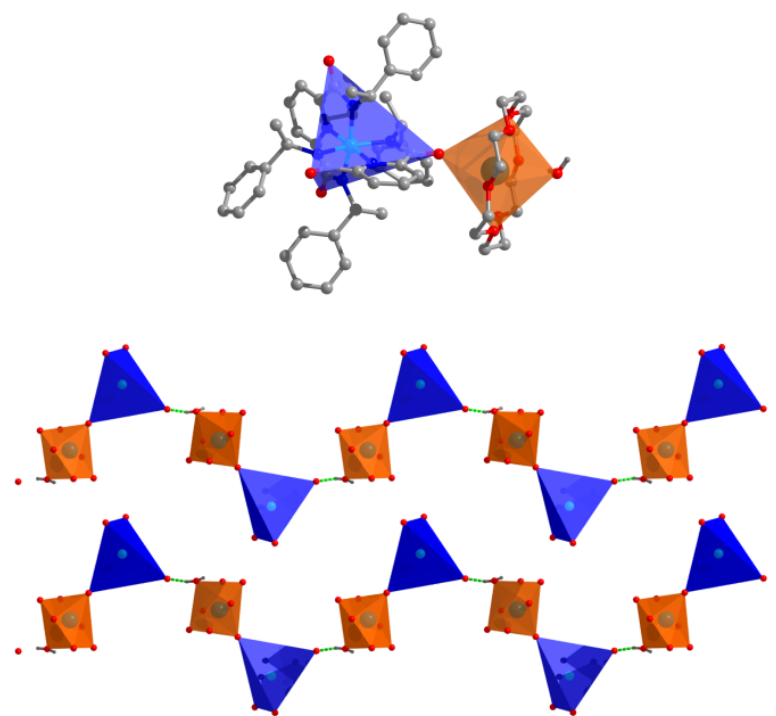

Fig. 3 (a) Polyhedral model of (18-crown-6)K[Co $\left.{ }^{\mathrm{III}}\left(R, R-\mathrm{L}^{1}\right)_{2}\right] \cdot \mathrm{H}_{2} \mathrm{O} \cdot \mathrm{MeCN}$ (1a), indicating tetrahedral orientation of the carbonyl groups. (b) helical chains viewed along the [100] direction. 


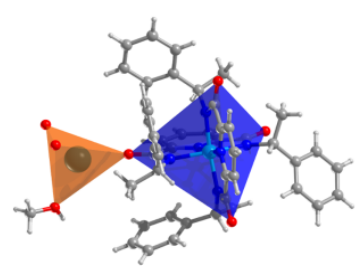

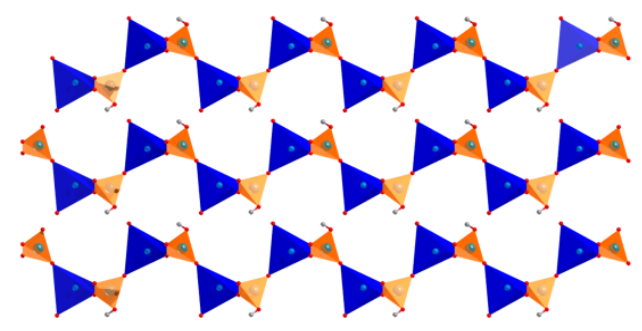

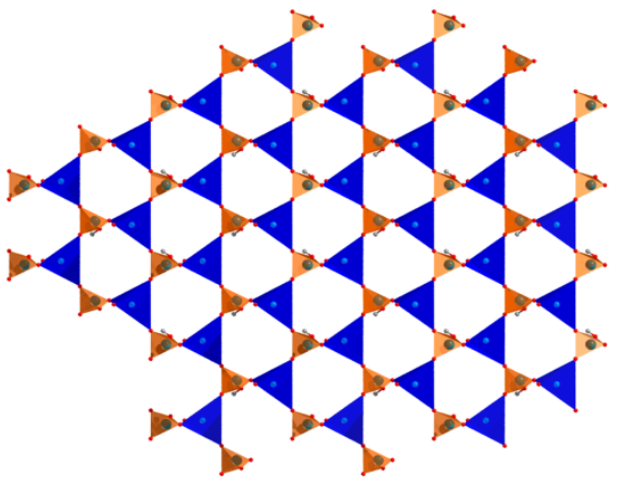

Fig. 4 (a) Polyhedral model of $\mathrm{K}\left[\mathrm{Co}^{\mathrm{III}}\left(\mathrm{R}, \mathrm{R}-\mathrm{L}^{1}\right)_{2}\right] \cdot \mathrm{MeOH}(\mathbf{1 b})$, indicating tetrahedral orientation of the carbonyl groups. (b) Layered structure of viewed along the edge of layers ([100] direction). (c) Honeycomb sheet viewed along the [001] direction.

The complex anion (Fig. 2) is cooordinated to the $[\mathrm{K}(18-$ 5 crown-6) $\left.\left(\mathrm{OH}_{2}\right)\right]^{+}$counterion with $\mathrm{O}(1)-\mathrm{K}(1)$ of $2.691(2) \AA$. There is also one molecule of acetonitrile of crystallisation. Hydrogen bonding between a hydrogen atom of the coordinated water molecule and a carbonyl group of an adjacent anion leads to formation of a helical chain along the 10 [010] direction (Fig 3b).

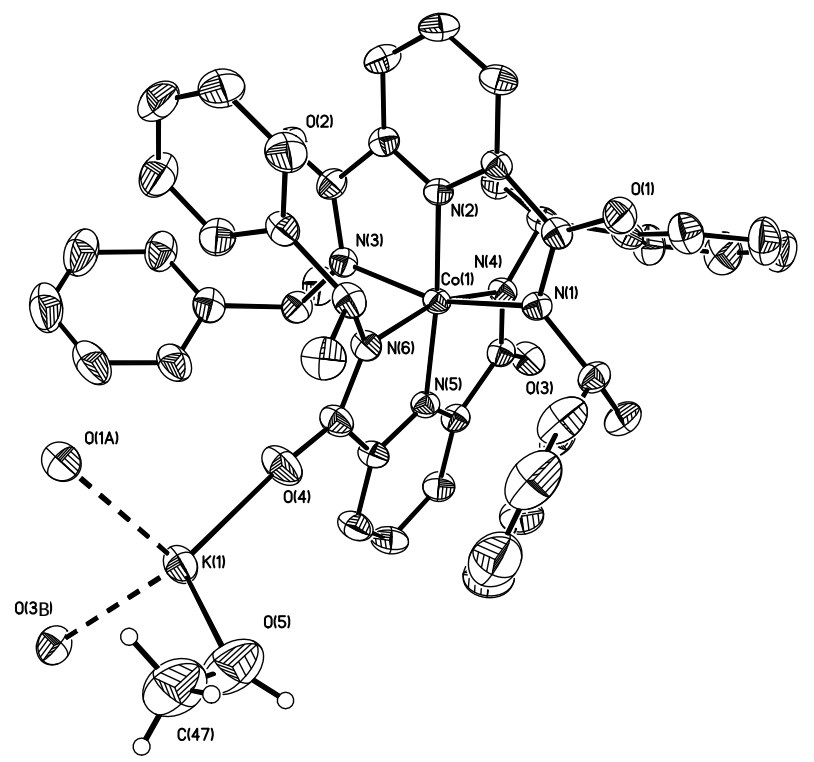

Fig. 5 Solid state structure of $\mathrm{K}\left[\mathrm{Co}^{\mathrm{III}}\left(\mathrm{R}, \mathrm{R}-\mathrm{L}^{1}\right)_{2}\right] . \mathrm{MeOH}(\mathbf{1 b})$ with thermal ellipsoids at $35 \%$ probability.A label indicates an atom at $(-x,-1 / 2+y, 2-z)$ and the $\mathrm{B}$ label indicates an atom at $(1-\mathrm{x},-1 / 2+\mathrm{y}, 2-\mathrm{z})$. Hydrogen atoms

15 have been omitted from the metal complex for clarity. Selected bond lengths $(\AA)$ and angles $\left({ }^{\circ}\right)$ : $\mathrm{Co}(1)-\mathrm{N}(5)$ 1.8556(15), $\mathrm{Co}(1)-\mathrm{N}(2)$

1.8568(15), $\mathrm{Co}(1)-\mathrm{N}(4) 1.978(2), \mathrm{Co}(1)-\mathrm{N}(6) 1.9838(19), \mathrm{Co}(1)-\mathrm{N}(3)$ $1.999(2), \mathrm{Co}(1)-\mathrm{N}(1) 2.0002(19), \mathrm{N}(5)-\mathrm{Co}(1)-\mathrm{N}(2)$ 173.92(9), N(5)-

$\mathrm{Co}(1)-\mathrm{N}(4) 81.79(8), \mathrm{N}(5)-\mathrm{Co}(1)-\mathrm{N}(6)$ 82.12(8), N(4)-Co(1)-N(6)

$20 \quad 163.76(7), \mathrm{N}(2)-\mathrm{Co}(1)-\mathrm{N}(3)$ 81.41(8), N(2)-Co(1)-N(1) 81.55(8), N(3)$\mathrm{Co}(1)-\mathrm{N}(1)$ 162.93(7). Angle between mean planes of diamidopyridine units of the ligands: $88.8^{\circ}$.

\section{$\mathrm{K}\left[\mathrm{Co}{ }^{\prime \prime \prime}\left(\mathrm{R}, \mathrm{R}-\mathrm{L}^{1}\right)_{2}\right] \cdot \mathrm{MeOH}(\mathbf{1 b})$}

Single crystals were grown by a slow diffusion of diethyl 25 ether into a solution of the complex in acetonitrile without addition of the crown ether. The compound crystallises in a monoclinic chiral $\mathrm{P} 2_{1}$ space group. The structure shown in Fig. 5 consists of the cobalt complex and a potassium counter ion. The potassium ion is coordinated - approximately 30 tetrahedrally - by one methanol ligand and the carbonyl groups of the three adjacent complex anions (Fig. 4a). The O$\mathrm{K}$ distances are between 2.50 and $2.64 \AA$.

The carbonyl groups of the anion are orientated in a tetrahedral array and three of the vertex $O$ atoms participate 35 in the formation of the extended network. This results in a 2D extended structure with honeycomb layers (Fig. $4 \mathrm{~b}$ and c).

We have analysed the crystal structures of previously reported achiral compounds of this type and note that in several cases extended structures with different topologies 40 are present; 1D chains ${ }^{19,22}$ and ribbons ${ }^{23}, 2 \mathrm{D}$ layers ${ }^{23}$ and $O D$ clusters/pairs. ${ }^{22}$

\section{(18-crown-6)K[Fe"'(R,R-L $\left.\left.{ }^{1}\right)_{2}\right](2)$}

Single crystals of complex $\mathbf{2}$ were grown by slow diffusion of ${ }_{45}$ diethyl ether into a saturated solution of the complex in acetonitrile. The compound crystallises in the monoclinic chiral space group $\mathrm{P} 2_{1}$, with two complex anions and two potassium ions coordinated to two crown ethers in the asymmetric unit

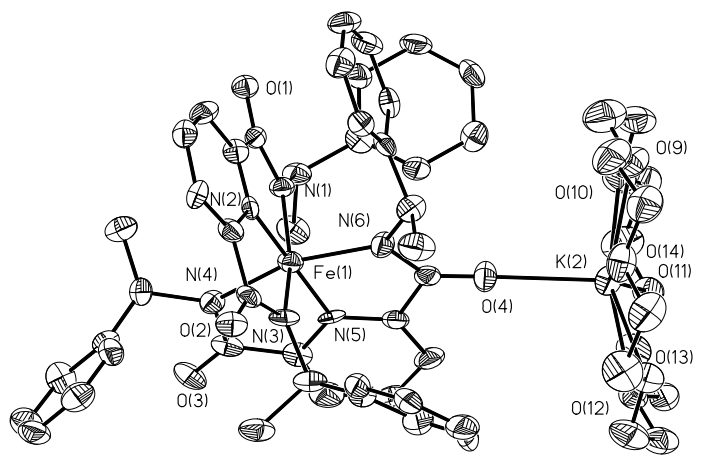

Fig. 6 Molecular structure of one of the crystallographic independent ion pairs $\left(18\right.$-crown-6) $\mathrm{K}\left[\mathrm{Fe}\left(R, R-\mathrm{L}^{1}\right)_{2}\right](2)$ with thermal ellipsoids at $50 \%$ probability. Hydrogen atoms omitted for clarity. Selected bond lengths $(\AA)$ and angles $\left({ }^{\circ}\right)$ : $\mathrm{Fe}(1)-\mathrm{N}(2) 1.887(7), \mathrm{Fe}(1)-\mathrm{N}(5) 1.891(7), \mathrm{Fe}(1)-\mathrm{N}(3)$ 55 1.982(8), $\mathrm{Fe}(1)-\mathrm{N}(1) 2.025(8), \mathrm{Fe}(1)-\mathrm{N}(6) 2.027(8), \mathrm{Fe}(1)-\mathrm{N}(4) 2.050(9)$, $\mathrm{N}(2)-\mathrm{Fe}(1)-\mathrm{N}(3)$ 81.2(4), N(2)-Fe(1)-N(1) 80.7(4), N(3)-Fe(1)-N(1) 161.9(3), N(5)-Fe(1)-N(6) 80.8(3), N(5)-Fe(1)-N(4) 80.1(3), N(6)-Fe(1)$\mathrm{N}(4)$ 160.7(3). Angle between the mean planes of diamidopyridine units of the ligands: $88.23^{\circ}$.

${ }_{60}$ One of the crown ethers was modelled as disorderd. The 
bond lengths and angles are similar to those of the corresponding Co ${ }^{\text {III }}$ compound.

Analogous to $\mathbf{1}$ the compound $\mathbf{2}$ forms [(18-crown6) $\mathrm{K}] \cdot\left[\mathrm{Fe}^{\prime \prime \prime}\left(R, R-\mathrm{L}^{1}\right)_{2}\right]$ ion pairs through coordination of the 5 potassium cation via one of the carbonyl oxygen atoms. Similarly there is no extended coordination structure but close contacts are observed between the potassium counterions and the stereogenic methyl groups of the neighbouring complex e.g. $\mathrm{K}(1)-\mathrm{H}(86 \mathrm{C})=2.817 \AA$. This leads 10 to a 1D chain like arrangement (Fig. 7).

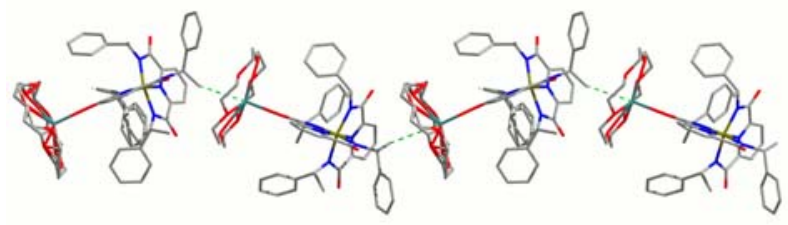

Fig. 7 “Chain” of discrete $\left[(18\right.$-crown-6)K $] \cdot\left[\mathrm{Fe}\left(R, R-\mathrm{L}^{1}\right)_{2}\right]$ units in 2.

\section{$\mathrm{K}\left[\mathrm{Co}{ }^{\prime \prime \prime}\left(\mathrm{S}, \mathrm{S}-\mathrm{L}^{2}\right)_{2}\right] \cdot 3 \mathrm{H}_{2} \mathrm{O}(3)$}

Crystals of $\mathbf{3}$ were obtained by a slow addition of diethyl 15 ether into a solution of the complex in acetonitrile in the presence of few drops of water. The compound crystallises in monoclinic chiral space group $\mathrm{P} 2{ }_{1}$.

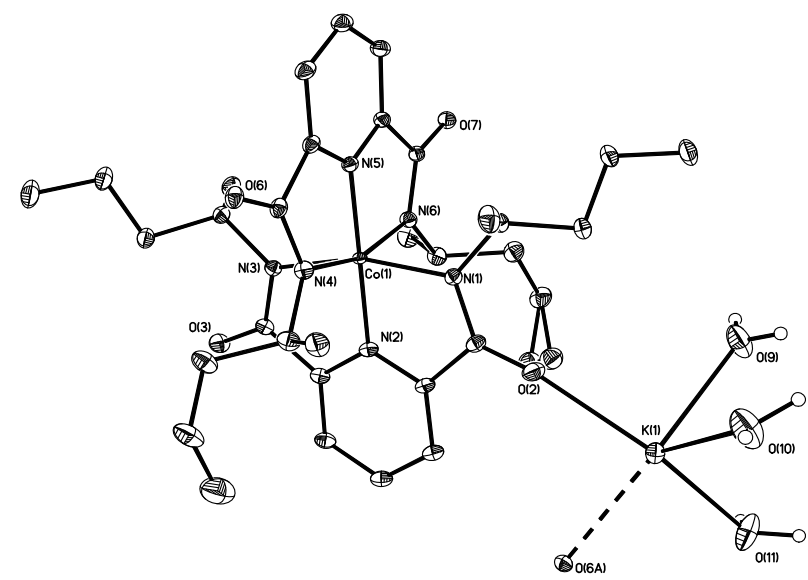

Fig. 8 Crystal structure of $\mathrm{K}\left[\mathrm{Co}^{\mathrm{III}}\left(S, S-\mathrm{L}^{2}\right)_{2}\right] \cdot 3 \mathrm{H}_{2} \mathrm{O}(\mathbf{3})$ with atomic

20 numbering and $50 \%$ thermal ellipsoids. The potassium cation is shown together with coordinated water molecules and the symmetry related (1$\mathrm{x}, 1 / 2+\mathrm{y}, 1-\mathrm{z})$ carbonyl oxygen atom $\mathrm{O}(6 \mathrm{~A})$. Selected bond lengths $(\AA)$ and angles $\left({ }^{\circ}\right)$ : $\mathrm{Co}(1)-\mathrm{N}(2) 1.856(2), \mathrm{Co}(1)-\mathrm{N}(5) 1.860(2), \mathrm{Co}(1)-\mathrm{N}(1)$ $1.961(2), \mathrm{Co}(1)-\mathrm{N}(3) 1.9631(19), \mathrm{Co}(1)-\mathrm{N}(6) 1.9740(17), \mathrm{Co}(1)-\mathrm{N}(4)$

$25 \quad 1.9741(18), \mathrm{K}(1)-\mathrm{O}(2) 2.6498(17), \mathrm{K}(1)-\mathrm{O}(11) 2.648(2), \mathrm{K}(1)-\mathrm{O}(10)$

$2.651(2), \mathrm{K}(1)-\mathrm{O}(9) 2.7003(19), \mathrm{K}(1)-\mathrm{O}(6) 2.8123(16), \mathrm{N}(2)-\mathrm{Co}(1)-\mathrm{N}(5)$

179.76(9), N(2)-Co(1)-N(1) 81.70(8), N(2)-Co(1)-N(3) 81.49(8), N(1)-

Co(1)-N(3) 163.19(7), N(5)-Co(1)-N(6) 81.57(7), N(2)-Co(1)-N(4)

98.47(7), N(5)-Co(1)-N(4) 81.61(7), N(3)-Co(1)-N(4) 90.71(8), N(6)-

$30 \mathrm{Co}(1)-\mathrm{N}(4) 163.17(7)$. Angle between mean planes of diamidopyridine units of the ligands: $87.7^{\circ}$.

In compound $\mathbf{3}$ the potassium counterion is coordinated to two carbonyls of adjacent complex anion tetrahedra as well as three water molecules (Fig. 8, Fig 9a). Two of the corners 35 of each tetrahedron participate in the formation of the extended structure, compared with three in the case of $\mathbf{1 b}$ and one in $\mathbf{1 a}$ and $\mathbf{2}$. This results in 1D extended zig-zag chains in the solid state (Fig. 9b). These chains are connected by $\mathrm{H}$ bonding between coordinated water molecules and
40 neighbouring $\mathrm{CO}$ groups.

a

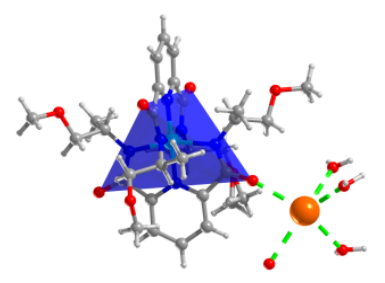

b

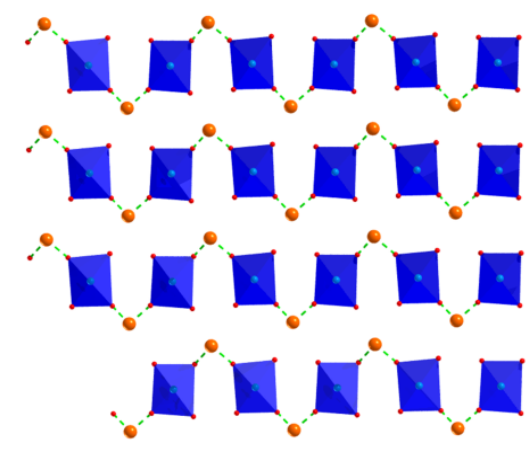

Fig. 9 Extended 1D zig-zag chain structure of $\mathrm{K}\left[\mathrm{Co}^{\mathrm{III}}\left(S, S-\mathrm{L}^{2}\right)_{2}\right] \cdot 3 \mathrm{H}_{2} \mathrm{O}(3)$. (a) Polyhedral model of the molecule, indicating the tetrahedral orientation of the carbonyl groups, (b) a simplified polyhedral view along the [100] direction.

\section{Synthesis of the TTF salts}

The compounds, $\mathbf{1 a}, \mathbf{2}$ and $\mathbf{3}$ were used in the subsequent syntheses of the TTF based molecular materials.

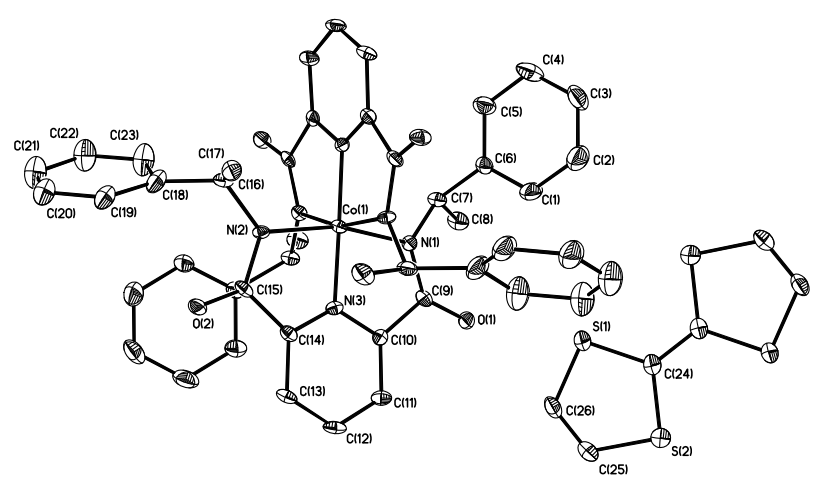

50 Fig. 10 Molecular structure of (TTF) $\left[\mathrm{Co}^{\mathrm{III}}\left(R, R-\mathrm{L}^{1}\right)_{2}\right](4)$ showing thermal ellipsoids at $50 \%$ probability. Hydrogen atoms have been removed for clarity. Selected bond lengths $(\AA)$ and angles $\left({ }^{\circ}\right)$ : $\mathrm{Co}(1)-\mathrm{N}(3) 1.848(2)$, $\mathrm{Co}(1)-\mathrm{N}(1)$ 1.958(2), $\mathrm{Co}(1)-\mathrm{N}(2)$ 1.976(3), N(3)-Co(1)-N(3') 176.13(19), $\mathrm{N}(3)-\mathrm{Co}(1)-\mathrm{N}(1)$ 82.67(11), N(3)-Co(1)-N(1') 100.12(10), N(1)-Co(1)$\mathrm{N}\left(1^{\prime}\right)$ 88.71(15), N(3)-Co(1)-N(2) 82.23(11), N(3')-Co(1)-N(2) 95.07(10), N(1)-Co(1)-N(2) 164.72(9), N(1')-Co(1)-N(2) 91.62(9), N(2)$\mathrm{Co}(1)-\mathrm{N}(2) 92.05(15)$. Angle between mean planes of diamidopyridine units of the ligands: $89.45^{\circ}$.

(TTF) $\left[\mathrm{CO}^{\prime \prime \prime}\left(\mathrm{R}, \mathrm{R}-\mathrm{L}^{1}\right)_{2}\right](4)$

60 Electrocrystallisation of $\mathbf{1 a}$ with TTF in dry THF under constant current conditions $(1 \mu \mathrm{A})$ gave black crystals of (TTF) $\left[\mathrm{Co}^{\prime \prime \prime}\left(R, R-\mathrm{L}^{1}\right)_{2}\right]$ (4) suitable for single crystal $\mathrm{X}$-ray diffraction and conductivity measurements. The compound crystallises in the chiral monoclinic $C_{2}$ space group. The ${ }_{65}$ asymmetric unit contains one ligand, half of a cobalt ion and half of an oxidized TTF molecule. There are two complete 
complex anions and two TTF molecules in the unit cell. The cobalt complex lies on a twofold axis through the cobalt as does the centroid of the $\mathrm{C}=\mathrm{C}$ bond of the oxidised TTF.

The bond lengths of the TTF molecule are consistent with 5 the values expected for the $\mathrm{TTF}^{+}$ion. ${ }^{24}$ There is no significant difference between the bond lengths within the complex anion compared to 1 . The ligand orientation (Fig. 11) is rather more symmetrical compared to the parent structure presumably as a result of the lack of coordinating postassium 10 in 3.

a

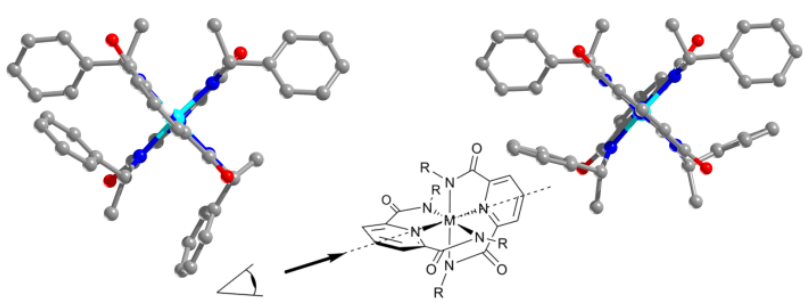

Fig. 11 Comparison of the orientation of the phenyl groups of the ligand $\mathrm{L}^{1}$, in (a) the parent compound $\mathbf{1 b}$ and (b) the TTF salt $\mathbf{4}$ as viewed along the pyridyl-metal-pyridyl axis of the molecule (inset)

15 In both crystal structures of the parent compound, $\mathbf{1 a}$ and $\mathbf{1 b}$, the two ligands do not have identical spatial configurations. The phenyl groups of one of the ligands point above and below the pyridyl plane, whereas the phenyl groups on the other ligand both point in the same direction (Fig. 11a). ${ }_{20}$ However, in the TTF salt 4 the ligand orientation is $C_{2}$ symmetric, with the two phenyl groups of each ligand arranged above and below the pyridyl mean plane (Fig. 11b).

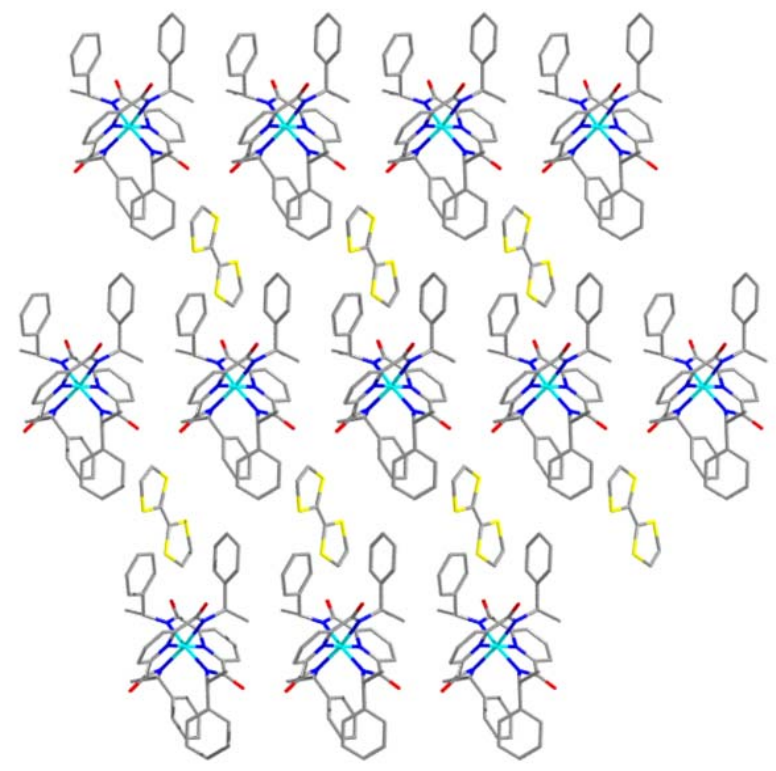

Fig. 12 Extended structure of $(\mathrm{TTF})\left[\mathrm{Co}{ }^{\mathrm{III}}\left(R, R-\mathrm{L}^{1}\right)_{2}\right](4)$. Hydrogen atoms 25 have been removed for clarity

The extended structure of the compound shows alternating layers of complex anions and TTF molecules, but the commonly observed stacked arrangement of the TTF
30 layer is not seen; the closest distance between the neighbouring TTF molecules is ca $9.5 \AA$. Correspondingly this material was found to be an insulator (two probe measurements, resistance $>10^{6} \Omega$ ). As can be seen from Fig 12 phenyl rings of the chiral anionic units interdigitate the ${ }_{35}$ cationic layers, potentially disrupting closer stacking between the TTF moieties.

\section{(TTF) [Co"'(S,S-L L $\left.\left.^{2}\right)_{2}\right] \cdot \operatorname{EtOAC}(5)$}

A new ligand $\mathrm{H}_{2}\left(S, S, L^{2}\right.$ ) was designed (Scheme 1) with the 40 expectation that the removal of the phenyl rings would eliminate the disruption of stacking of the donor molecules. In addition the smaller anion could be expected to allow closer cation packing and enhance the conductivity. Several attempts to electrocrystallise the modified complex with TTF ${ }_{45}$ have proven fruitless, most likely due to the high solubility of the resulting material. We therefore decided to approach the synthesis using a different method, namely the salt metathesis, using the mixed-valence TTF salt $(\mathrm{TTF})_{3}\left(\mathrm{BF}_{4}\right)_{2} \cdot{ }^{25}$

(TTF) $\left[\mathrm{Co}^{\prime \prime \prime}\left(S, S-\mathrm{L}^{2}\right)_{2}\right]$-EtOAc (5) was obtained by an addition 50 of the acetonitrile solution of $(\mathrm{TTF})_{3}\left(\mathrm{BF}_{4}\right)_{2}$ to the solution of $\mathrm{K}\left[\mathrm{Co}^{\prime \prime \prime}\left(S, S-\mathrm{L}^{2}\right)_{2}\right] \cdot 3 \mathrm{H}_{2} \mathrm{O}(3)$ in acetonitrile. Single crystals of the product were obtained by a slow diffusion of EtOAc into the solution. The compound was characterised using single crystal X-ray diffraction, conductivity measurements, CD and ${ }_{55}$ UV spectrometry and cyclic voltammetry.

(TTF) $\left[\mathrm{Co}^{\prime \prime \prime}\left(S, S-\mathrm{L}^{2}\right)_{2}\right]$.EtOAC (5) crystallises in monoclinic chiral $\mathrm{P} 2_{1}$ space group. The asymmetric unit contains the complex anion, one TTF cation and one molecule of ethyl acetate.

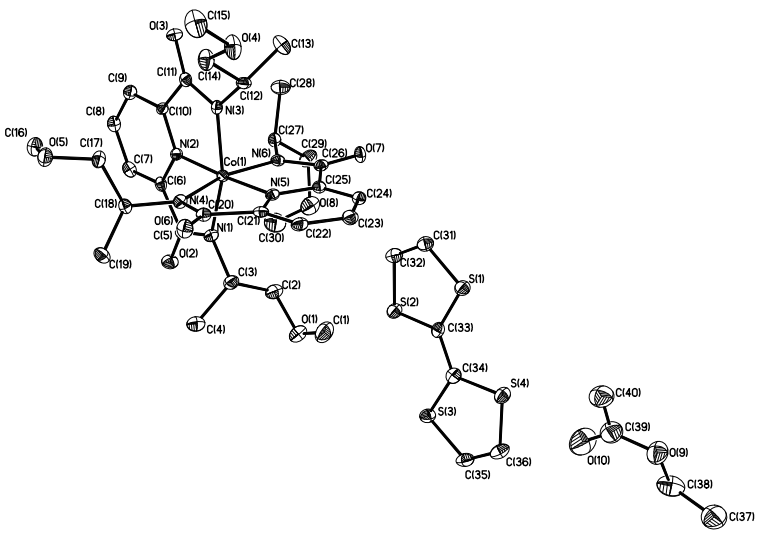

Fig. 13 Molecular structure of (TTF) $\left[\mathrm{Co}^{\mathrm{III}}\left(S, S-\mathrm{L}^{2}\right)_{2}\right] \cdot$ EtOAc (5) showing thermal ellipsoids at $50 \%$ probability, the hydrogen atoms were removed for clarity. Selected bond lengths $(\AA)$ and angles $\left({ }^{\circ}\right)$ : $\mathrm{Co}(1)-\mathrm{N}(5) 1.848(2)$, $\mathrm{Co}(1)-\mathrm{N}(2)$ 1.856(2), $\mathrm{Co}(1)-\mathrm{N}(4)$ 1.963(2), $\mathrm{Co}(1)-\mathrm{N}(1)$ 1.964(2), $\mathrm{Co}(1)-$ ${ }_{65} \mathrm{~N}(6) 1.978(2), \mathrm{Co}(1)-\mathrm{N}(3) 1.980(2), \mathrm{N}(5)-\mathrm{Co}(1)-\mathrm{N}(2) 176.49(9), \mathrm{N}(5)-$ Co(1)-N(4) 81.70(9), N(2)-Co(1)-N(1) 81.71(9), N(5)-Co(1)-N(6)

81.61(9), N(4)-Co(1)-N(6) 163.06(9), N(2)-Co(1)-N(3) 81.48(9), N(4)Co(1)-N(3) 91.97(9), N(1)-Co(1)-N(3) 162.87(9). mean planes of diamidopyridine units of the ligands: $89.63^{\circ}$.

70 The bond lengths of the TTF molecule are consistent with expected values for $\mathrm{TTF}^{+}{ }^{24}$ There are no significant changes in bond length within the complex anion compared to $\mathbf{3}$. Similar to 4 , the ligand orientation in this structure is much more symmetrical compared to the parent compound (Fig. 75 14). 
a

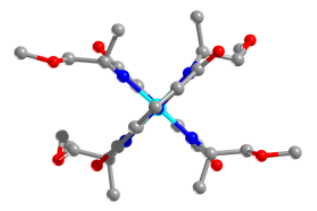

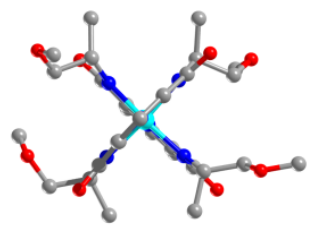

Fig. 14 Comparison of the orientation of the methoxy groups of the ligand in (a) the parent compound $\mathbf{3}$ and (b) in $\mathbf{5}$. View along the main axis of the molecule (see Fig. 11).

${ }_{5}$ As in case of compound $\mathbf{1}$ the arrangement of the two ligands in the parent compound $\mathbf{3}$ is not identical. The methoxy groups of one of the ligands point outward from the metal centred octahedron, whereas the corresponding groups of the second ligand point inwards (Fig. 14). The complex anion

10 in the TTF salt $\mathbf{5}$ displays more symmetrical configuration with one of the methoxy groups pointing outwards and one inwards in both ligands.

The extended structure is composed of anionic and cationic layers. Rather than a stack of TTF units, the cationic 15 layer consists of alternating TTF and ethyl acetate molecules (Fig. 15). In addition, methoxy groups from the anion penetrate the cationic layer. Ethyl acetate was used as a nonsolvent in the crystallisation, and so its incorporation is

rather unexpected. ${ }^{\ddagger}$ There are several short contacts and ${ }_{20}$ hydrogen bonds within the cationic layer between hydrogens of TTF units with oxygen atoms of solvent molecule and complex anion: $\mathrm{H}(36 \mathrm{~A})-\mathrm{O}(10) 2.507 \AA ⿻ \mathrm{H}(31 \mathrm{~A})-\mathrm{O}(7) 2.532 \AA$, $\mathrm{H}(32 \mathrm{~A})-\mathrm{O}(8) 2.286 \AA, \mathrm{H}(31 \mathrm{~A})-\mathrm{O}(2) 2.385 \AA, \mathrm{H}(35 \mathrm{~A})-\mathrm{O}(3) 2.706$ $\AA, H(35 A)-O(6) 2.26 \AA$.

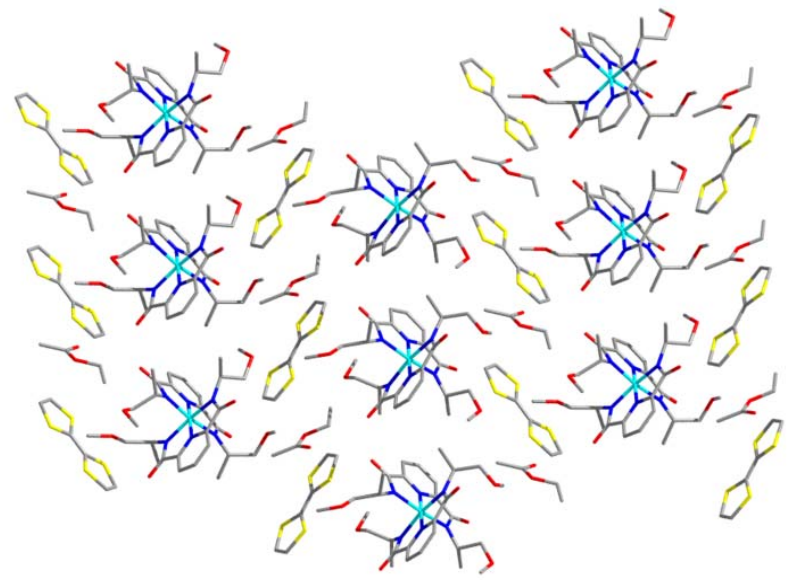

Fig. 15 Extended structure of compound 5. Hydrogen atoms have been removed for clarity

Table 1 Detail of crystal solution and refinement

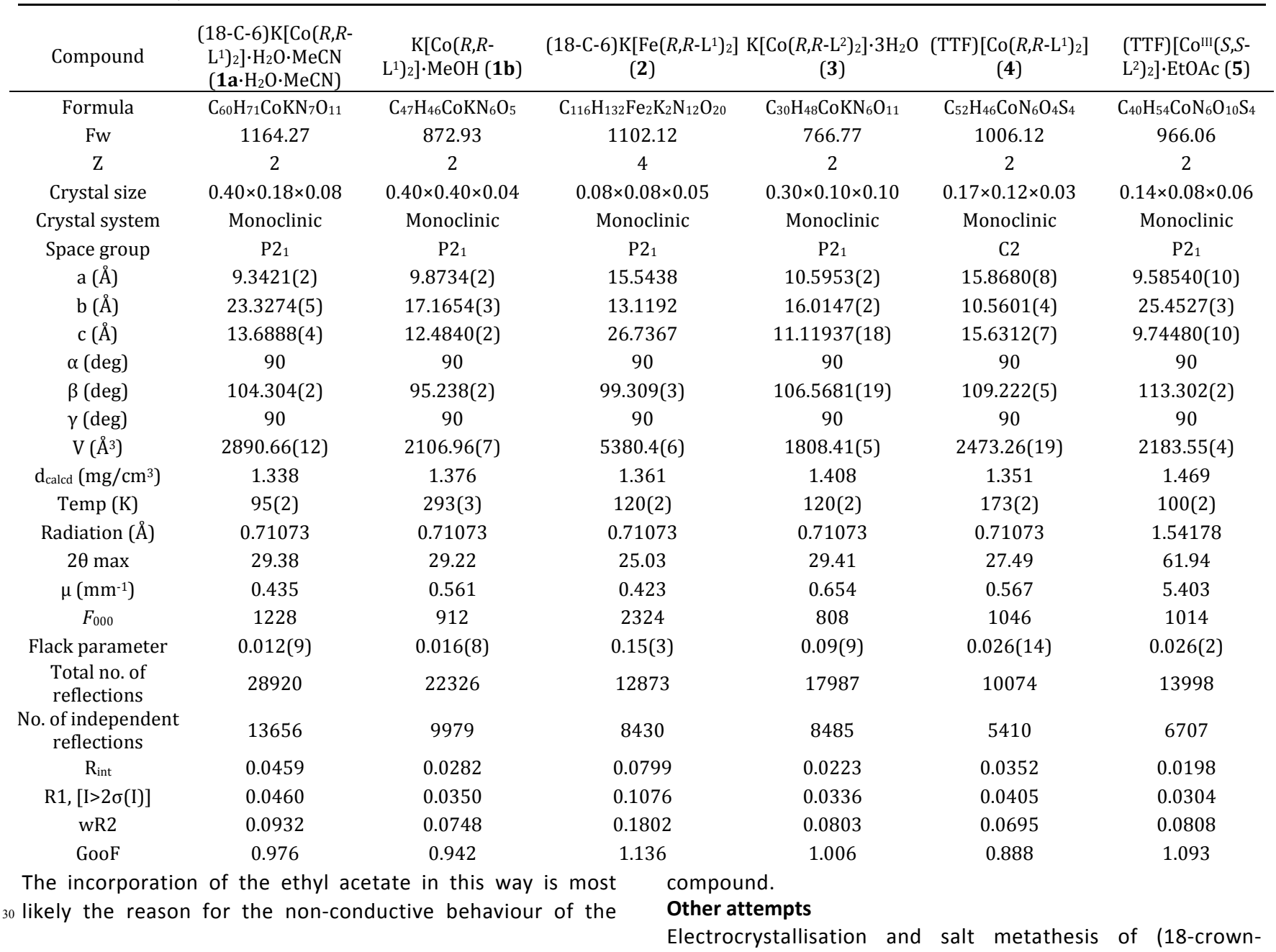


6) $\mathrm{K}\left[\mathrm{Fe}^{\text {IIII }}\left(R, R-\mathrm{L}^{1}\right)_{2}\right](2)$ to obtain its TTF salt yielded insoluble microcrystalline solids.

\section{UV-Vis and CD spectrometry}

5 The UV-Vis spectrum of intensely coloured (TTF) [Co"I $(S, S$ $\left.\left.\mathrm{L}^{2}\right)_{2}\right]$-EtOAc (5) shows similar features to the parent complex $\mathrm{K}\left[\mathrm{Co}{ }^{\prime \prime \prime}\left(S, S-\mathrm{L}^{2}\right)_{2}\right] \cdot 3 \mathrm{H}_{2} \mathrm{O}(3)$ with additional bands in the $250-350$ $\mathrm{nm}$ region (Fig. 16 green line).

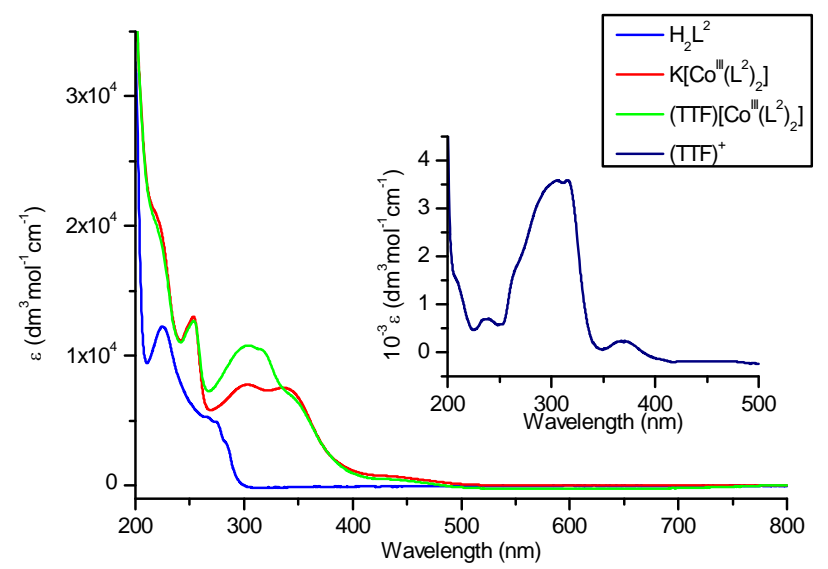

Fig. $16 \mathrm{UV}-\mathrm{V}$ is spectra of the $\mathrm{H}_{2}\left(S, S-\mathrm{L}^{2}\right)$ proligand, the $\mathrm{K}\left[\mathrm{Co}^{\mathrm{III}}(S, S-\right.$ $\left.\left.\mathrm{L}^{2}\right)_{2}\right] \cdot 3 \mathrm{H}_{2} \mathrm{O}(\mathbf{3})$, the charge transfer salt (TTF) $\left[\mathrm{Co}^{\mathrm{III}}\left(S, S-\mathrm{L}^{2}\right)_{2}\right] \cdot \operatorname{EtOAc}(\mathbf{5})$ and a calculated spectrum of $\mathrm{TTF}^{+}$(inset).

Subtraction of the sprectrum of $\mathbf{3}$ from $\mathbf{5}$ gave the inset 15 spectrum which must originate from the presence of the $\mathrm{TTF}^{+}$moiety. In 'free' $\mathrm{TTF}^{+}$this feature is expected at $430 \mathrm{~nm}$ so a strong hypsochromic shift (1.2-1.5 eV) is thus apparent into the region usually associated with the albeit less intense UV absorbance of neutral TTF. ${ }^{26-27}$ We propose that this 20 arises from a strong interaction beween the cationic donor molecule and the anion in the solution. Incidentally, no bands characteristic for $\left(\mathrm{TTF}^{+}\right)_{2}$ dimers are observed. Strong shifts in UV-Vis spectrum of TTF species were previously observed for species trapped inside zeolites. ${ }^{28}$

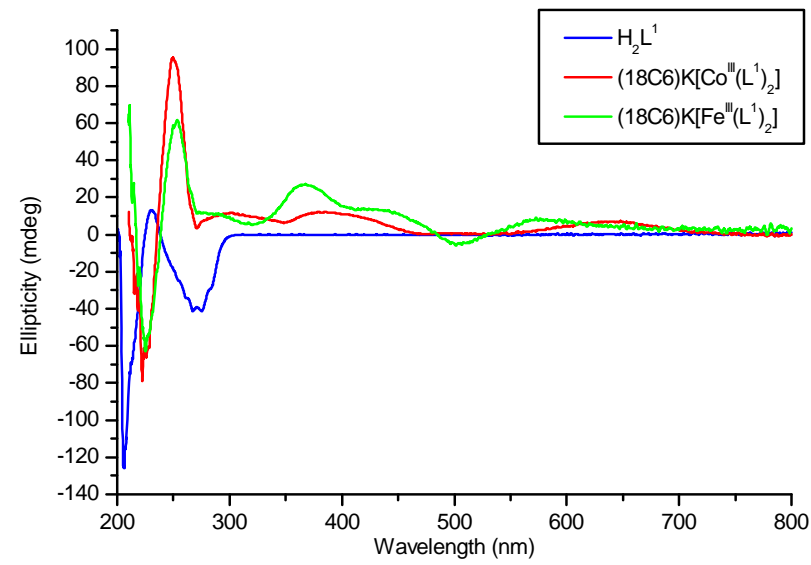

Fig. $17 \mathrm{CD}$ spectra of the protonated ligand $\mathrm{H}_{2}\left(R, R-\mathrm{L}^{1}\right)$ and its complexes (18-crown-6)K $\left[\mathrm{M}^{\mathrm{III}}\left(R, R-\mathrm{L}^{1}\right)_{2}\right](\mathrm{M}=\mathrm{Co}, \mathrm{Fe})(\mathbf{1 a}$ and 2) $(0.1 \mathrm{mM}$ solutions in $\mathrm{MeCN})$.

The CD spectrum of $\mathrm{H}_{2}\left(R, R-L^{1}\right)$ does not show any features 30 between $300-700 \mathrm{~nm}$. In the UV region two strong negative bands are recorded, at 206 and $270 \mathrm{~nm}$. Spectra of both Co ${ }^{\prime \prime \prime}$ and $\mathrm{Fe}^{\mathrm{III}}$ complexes of $\mathrm{L}^{1}$ are similar in their features, with intense bands in the $\mathrm{CT}$ region (200-500 nm) with the strongest bands in the $200-300 \mathrm{~nm}$ range, and weak broad 35 features in the $d$-d region (550-750 nm). Low intensity (ellipticity) of those bands can be explained by the weak expression of chirality at the metal centre (the complexes are not chiral-at-metal). An interesting feature is the apparent inversion of the spectrum while comparing spectra of the 40 proligand and the complex (Fig. 17).

The spectrum of the methoxy ligand $\mathrm{H}_{2}\left(S, S-L^{2}\right)$ shows almost no features in the measured spectral range, the only weak band can be observed at 250-300 nm (Fig. 18 red line). This is most likely due to the absence of strongly absorbing 45 functional groups near the chiral centres of the molecule. CD spectra of complexes $\mathbf{1}$ and $\mathbf{3}$ show broad, weak features in the $550-750 \mathrm{~nm}$ region, originating from the $\mathrm{d}$ - $\mathrm{d}$ transitions. Several strong CT bands can be observed in the 200-500 nm region, with the strongest bands between 200 and $300 \mathrm{~nm}$. 50 Similar to the $\mathrm{H}_{2}\left(R, R-\mathrm{L}^{1}\right)$ case, the spectra of the complex seem to be reversed vertically compared to the spectra of its proligand.

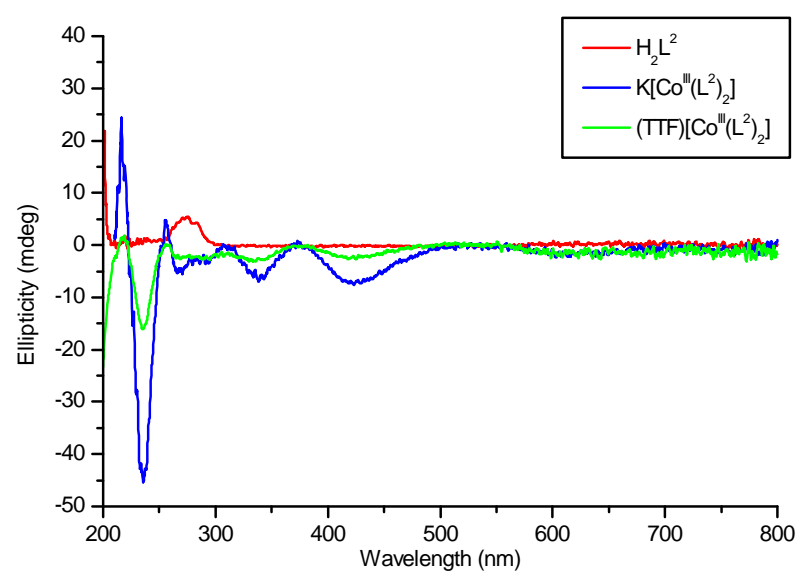

Fig.18 CD spectra of the $\mathrm{H}_{2}\left(S, S-\mathrm{L}^{2}\right)$ proligand, its complex $\mathrm{K}\left[\mathrm{Co}^{\mathrm{III}}(S, S\right.$ $\left.\left.55 \mathrm{~L}^{2}\right)_{2}\right] \cdot 3 \mathrm{H}_{2} \mathrm{O}(\mathbf{3})$ and the charge transfer salt $(\mathrm{TTF})\left[\mathrm{Co}^{\mathrm{III}}\left(S, S-\mathrm{L}^{2}\right)_{2}\right] \cdot$ EtOAc (5) $(0.1 \mathrm{mM}$ solutions in $\mathrm{MeCN})$.

The CD spectrum of the TTF salt $\mathbf{5}$ shows similar features to the spectrum of the parent complex 3 (Fig. 18 blue and green lines). No measurable effects originating from the 60 asssociation of the $\mathrm{TTF}^{+}$ion were observed. This accords with the similarity of the UV-vis spectra of the two compounds.

\section{Cyclic voltammetry}

UV-Vis studies and the crystal structures show that the ${ }_{65}$ pyridine amide complexes display an apparent affinity to TTF $^{+}$ ions. This prevents formation of the TTF stacks and thus promotes the non-conductive behaviour of those materials. To further investigate this phenomenon cyclic voltammograms of the parent complex $\mathrm{K}\left[\mathrm{Co}^{\prime \prime \prime}\left(S, S-\mathrm{L}^{2}\right)_{2}\right] \cdot 3 \mathrm{H}_{2} \mathrm{O}$ 70 (3) were compared with (TTF) $\left[\mathrm{CO}^{\prime \prime \prime}\left(S, S-\mathrm{L}^{2}\right)_{2}\right] \cdot \operatorname{EtOAc}(5)$ and TTF. The voltammograms were recorded without supporting electrolyte $^{\S}$ in order to observe only the interactions between the non-innocent species in the solution, and this results in broadness dues to ohmic effects. ${ }^{29}$ The scans were 
started at positive potentials and are reported relative to the $\mathrm{Ag} / \mathrm{AgCl}(3 \mathrm{M} \mathrm{KCl})$ reference electrode.

For 3 a wave, with $E_{1 / 2} \sim 1.42 \mathrm{~V}\left(\Delta \mathrm{E}_{\mathrm{p}}=0.56 \mathrm{~V}\right)$ was presumed to correspond to the $\mathrm{Co}^{\mathrm{III}} / \mathrm{Co}^{\mathrm{IV}}$ couple, given that 5 the $\mathrm{Co}(\mathrm{II})$ dianion is readily oxidised by $\mathrm{O}_{2}$ and this ligand environment is known to stabilise the higher oxidation states (vide supra). The CV of TTF (Fig. 19 inset) gave two waves as expected corresponding to the first and second oxidations $\left(E_{1 / 2}=0.34 \mathrm{~V}\right.$ and $\left.0.79 \mathrm{~V}\right)$.

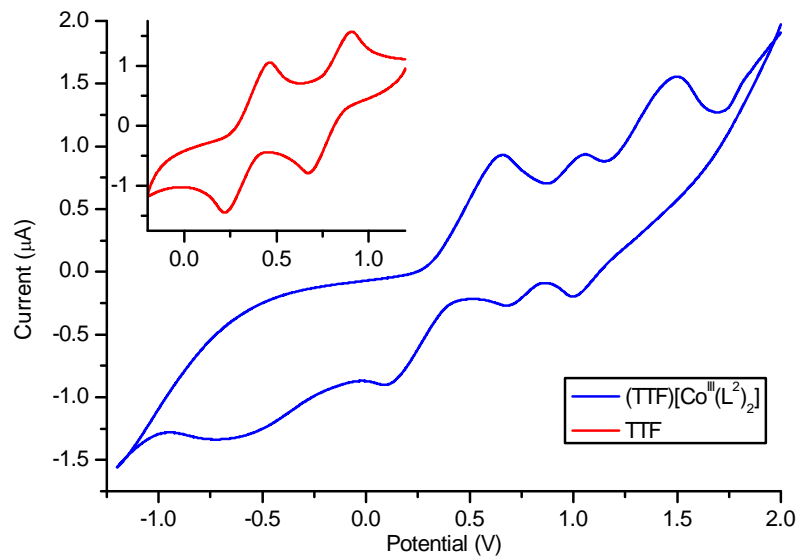

Fig. 19 Cyclic voltammogram of (TTF) $\left[\mathrm{Co}^{\mathrm{III}}\left(S, S-\mathrm{L}^{2}\right)_{2}\right] \cdot$ EtOAc (5) in acetonitrile $\left(0.1 \mathrm{mM}\right.$ solution) and TTF (inset) $\left(0.1 \mathrm{mM} \mathrm{NaPF}_{6}\right.$ solution in acetonitrile), scan rate $100 \mathrm{mV} / \mathrm{s}$

The $\mathrm{TTF}^{+}$salt 5 (Fig. 19) shows features originating from both 15 the TTF moiety ( 0 to $1.3 \mathrm{~V}$ ) and the complex anion ( -1 to 1.75 V). The peaks associated with TTF $(0.38 \mathrm{~V}$ and $0.87 \mathrm{~V})$ are shifted towards slightly higher potentials compared to the isolated species in the presence of the same concentration of $\mathrm{PF}_{6}{ }^{-}$. The $\mathrm{Co}^{\mathrm{III}} / \mathrm{Co}^{\mathrm{IV}}$ wave $\mathrm{E}_{1 / 2}$ of $1.25 \mathrm{~V}$ is significantly lower 20 than the value for the parent compound 3 (1.42 V). Most interestingly however the peak currents associated with the first redox step (TTF/TTF ${ }^{+}$) are significantly larger than those for the second step $\left(\mathrm{TTF}^{+} / \mathrm{TTF}^{2+}\right)$. This is consistent with a Chemical-Electrochemical (CE) process in which the $\mathrm{TTF}^{+}$

25 undergoes a chemical process - association with the anion to form a soluble assembly - which reduces its concentration in the region of the electrode. Formation of such assemblies has been observed in TTF compounds ${ }^{30-32}$ as well as in several other types of materials and there is a growing body of 30 evidence that the formation of such assemblies is a key step in crystallisation processes. ${ }^{33}$

\section{Conclusions}

The first optically pure anionic complexes of pyridinedicarboxyamido ligands have been synthesised. The 35 complexes show interesting extended structures, from OD discrete units through $1 \mathrm{D}$ zig-zag chains to 2D honeycomb layers, formed by coordination of the potassium counterion by carbonyl oxygen atoms of the ligands.

The compounds were tested for their application in the 40 construction of charge transfer materials with tetrathiafulvalene. The materials (TTF) $\left[\mathrm{Co}^{\prime \prime \prime}\left(R, R-\mathrm{L}^{1}\right)_{2}\right](4)$ and $(\mathrm{TTF})\left[\mathrm{Co}^{\prime \prime \prime}\left(S, S-\mathrm{L}^{2}\right)_{2}\right] \cdot$ EtOAc (5) were characterised by single crystal X-ray diffraction and conductivity measurements. Both compounds exhibit similar layered structures with no 45 TTF stacking, resulting in a non-conductive behaviour.

Cyclic voltammetry and spectroscopic evidence points to formation of $[\mathrm{TTF}]^{+} \cdot\left[\mathrm{Co}^{\prime \prime \prime}\left(\mathrm{L}^{\mathrm{n}}\right)_{2}\right]^{-}$assemblies in the solution and this mirrors the observed solid state structure in which stoichiometric $[\mathrm{TTF}]^{+} \cdot\left[\mathrm{Co}^{\prime \prime \prime}\left(\mathrm{L}^{\mathrm{n}}\right)_{2}\right]^{-}$rather than electrically ${ }_{50}$ conductive non-stoichiometric phases are observed.

\section{Experimental}

\section{General considerations}

Where necessary, procedures were carried out under an inert atmosphere of argon by using a dual manifold vacuum/argon 55 line and standard Schlenk techniques, or in an MBraun dry box. Solvents were dried by refluxing for three days under dinitrogen over the appropriate drying agents (potassium for THF; sodium-potassium alloy for diethyl ether; calcium hydride for dichloromethane and acetonitrile) and degassed ${ }_{60}$ before use. Solvents were stored in glass ampoules under argon. All glassware and cannulae were stored in an oven (>373 K). Most chemicals and reagents were purchased from either Aldrich Chemical Company, Acros Chemical Company, Lancaster, Alfa Aesar or Strem and used without further 65 purification unless otherwise stated. Anhydrous $\mathrm{CoCl}_{2}{ }^{34}$, pyridine-2,6-dicarbonyl dichloride ${ }^{35}$ and tetrathiafulvalenium tetrafluoroborate ${ }^{25}$ were prepared according to the literature procedures. Deuterated solvents were freeze-thaw degassed and dried by heating to their normal boiling points over 70 potassium (or calcium hydride for $\mathrm{d}^{2}$-dichloromethane) in vacuo for 3 days before vacuum distilling (trap-to-trap) to a clean, dry Young's tap ampoule and being stored in the dry box. Deuterated chloroform was dried in the bottle over molecular sieves ( $4 \AA$ ). Triethylamine was dried by refluxing 75 under dinitrogen over calcium hydride for 3 days. Potassium hydride dispersion in mineral oil was placed in a Schlenk vessel under an inert atmosphere and washed two times with diethyl ether and once with pentane to remove the oil. The solid was subsequently dried in vacuo and stored in the dry 80 box.

NMR spectra were recorded on Bruker Spectrospin $300 / 400 / 500 \mathrm{MHz}$ spectrometers. The spectra were internally referenced using the residual protio solvent $\left(D_{2} O, C_{3} C N\right.$ etc.) resonance relative to tetramethylsilane $(\delta=0 \mathrm{ppm})$. ESI 85 mass spectra were measured on a Bruker Esquire 2000 spectrometer. Infra-Red spectra were measured using a Perkin-Elmer FTIR spectrometer. Elemental analyses were performed by Warwick Analytical Services and Medac Ltd. The crystal data was collected using an Oxford Diffraction ${ }_{90}$ Gemini $R$ and Siemens SMART CCD single crystal diffractometers. Structures were solved by direct methods using SHELX (TREF) ${ }^{36-37}$ with additional light atoms found by Fourier methods. Crystal refinement was performed using SHELX97. ${ }^{37}$ CD spectra were recorded using Jasco J-810 95 (calibrated using $0.060 \%$ ACS for intensity and a holmium filter for wavelength). Sample concentrations were chosen to keep the high tension voltage below $600 \mathrm{~V}$. The standard parameters used were: bandwidth $1 \mathrm{~nm}$; response time $1 \mathrm{sec}$; 
wavelength scan range $200-800 \mathrm{~nm}$; data pitch $0.2 \mathrm{~nm}$; and scanning speed $100 \mathrm{~nm} / \mathrm{min}$, accumulation 4 .

\section{$\mathrm{N}^{2}, \mathrm{~N}^{6}$-bis $((R)-\alpha$-methylbenzyl)pyridine-2,6-dicarboxamide $\mathrm{H}_{2}\left(R, R-L^{1}\right)$}

${ }_{5}$ Pyridine-2,6-dicarbonyl dichloride $(2.04 \mathrm{~g}, 10 \mathrm{mmol})$ was dissolved in dry DCM $(50 \mathrm{ml})$. $(R)-(+)-\alpha$-methylbenzylamine $(2.42 \mathrm{~g}, 2.54 \mathrm{ml}, 20 \mathrm{mmol})$ and dry triethylamine $(2.02 \mathrm{~g}, 2.8$ $\mathrm{ml}, 20 \mathrm{mmol}$ ) were added dropwise and the solution was stirred for $2 \mathrm{~h}$. The reaction mixture was washed with water $10(3 \times 50 \mathrm{ml})$ and dried over $\mathrm{MgSO}_{4}$. The solvent was removed under reduced pressure and the obtained white solid was recrystallised from DCM/pentane. Yield $2.7 \mathrm{~g}(72 \%)$.

Elemental Analysis found (Calculated for $\mathrm{C}_{23} \mathrm{H}_{23} \mathrm{~N}_{3} \mathrm{O}_{2}$ ) \%: C 73.63 (73.97), H 6.50 (6.21), N 10.99 (11.25).

${ }_{15}{ }^{1} \mathrm{H}$ NMR $\left(300 \mathrm{MHz}, 298 \mathrm{~K}, \mathrm{CDCl}_{3}\right) \delta_{\mathrm{H}} 1.46\left(6 \mathrm{H}, \mathrm{d}, \mathrm{J}_{\mathrm{HH}}=7 \mathrm{~Hz}, \mathrm{CH}_{3}\right)$, $5.20\left(2 \mathrm{H}, \mathrm{dt}, \mathrm{J}_{\mathrm{HH}}=8 \mathrm{~Hz}, \mathrm{CH}\right), 7.15-7.30(10 \mathrm{H}, \mathrm{m}, \mathrm{ArH}), 7.89(3 \mathrm{H}$, $\left.\mathrm{dd}, \mathrm{J}_{\mathrm{HH}}=7 \mathrm{~Hz}, \mathrm{ArH}\right), 8.23\left(2 \mathrm{H}, \mathrm{d}, \mathrm{J}_{\mathrm{HH}}=8 \mathrm{~Hz}, \mathrm{NH}\right)$

${ }^{13} \mathrm{C}$ NMR $\left(100 \mathrm{MHz}, 298 \mathrm{~K}, \mathrm{CDCl}_{3}\right) \delta_{\mathrm{C}} 21.9\left(\mathrm{CH}_{3}\right), 49.1(\mathrm{C}-\mathrm{H})$, 125.1 (ph), 126.1, 127.6, 128.9, 139.1 (pyr), 143.0, 148.8, $20162.6(\mathrm{C}=0)$

$\mathrm{MS}\left(\mathrm{ESI}^{+}\right) \mathrm{m} / \mathrm{z} 396.17\left([\mathrm{M}+\mathrm{Na}]^{+}\right)$

IR $\left(\mathrm{cm}^{-1}\right)$ v 3610, $3395(\mathrm{~N}-\mathrm{H}), 1713,1663(\mathrm{C}=\mathrm{O}), 1508(\mathrm{~N}-\mathrm{H})$, 1445 (C-C ar.),1256, 1183, 1100, 1073 (C-H ar.), 1000, 840, 698 (C-H ar)

\section{${ }_{25} \mathbf{N}^{2}, \mathbf{N}^{6}$-bis((S)-1-methoxypropan-2-yl)pyridine-2,6- dicarboxyamide $\mathrm{H}_{2}\left(S, S-L^{2}\right)$}

Pyridine-2,6-dicarbonyl dichloride $(1.0 \mathrm{~g}, 4.8 \mathrm{mmol})$ was dissolved in dry DCM $(20 \mathrm{ml})$ under argon. $S-(+)-1-$ methoxy-2propylamine $(1.08 \mathrm{ml}, 10.2 \mathrm{mmol})$ was added dropwise and 30 the mixture was stirred for $15 \mathrm{~min}$. Dry TEA ( $6 \mathrm{ml}$ ) was added and the mixture was stirred at ambient temperature overnight. The mixture was washed with water $(3 \times 20 \mathrm{ml})$ and dried over sodium sulphate. The solvent was removed under reduced pressure. The product was recrystallised from ${ }_{35} \mathrm{DCM} /$ pentane (white solid). Yield $1.2 \mathrm{~g}$ (78\%).

Elemental Analysis found (Calculated for $\mathrm{C}_{15} \mathrm{H}_{23} \mathrm{~N}_{3} \mathrm{O}_{4}$ ) \%: C 58.45 (58.24), H 7.60 (7.49), N 13.64 (13.58)

${ }^{1} \mathrm{H}$ NMR $\left(400 \mathrm{MHz}, 298 \mathrm{~K}, \mathrm{CDCl}_{3}\right) \delta_{\mathrm{H}} 1.33\left(6 \mathrm{H}, \mathrm{d},{ }^{3} \mathrm{~J}_{\mathrm{HH}}=6.8 \mathrm{~Hz}\right.$, $\left.-\mathrm{CH}_{3}\right), 3.42\left(6 \mathrm{H}, \mathrm{s},-\mathrm{OCH}_{3}\right), 3.46-3.56\left(4 \mathrm{H}, \mathrm{m}, \mathrm{CH}_{2}\right), 4.29-4.42$

$40(2 \mathrm{H}, \mathrm{m}, \mathrm{CH}), 7.92-8.05(3 \mathrm{H}, \mathrm{m}(\mathrm{s}+\mathrm{t}), \mathrm{NH}, \mathrm{py}), 8.32\left(2 \mathrm{H}, \mathrm{d},{ }^{3} \mathrm{~J}_{\mathrm{HH}}\right.$ $=7.8 \mathrm{~Hz}, \mathrm{pyr}$ )

${ }^{13} \mathrm{C}$ NMR $\left(100 \mathrm{MHz}, 298 \mathrm{~K}, \mathrm{CDCl}_{3}\right) \delta_{\mathrm{C}} 17.7(-\mathrm{CH} 3), 45.0(\mathrm{CH})$, $59.1(-\mathrm{OCH} 3), 75.4(\mathrm{CH} 2), 124.8,138.9,148.8$ (ру), 162.8 (C=O)

${ }_{45} \mathrm{MS}\left(\mathrm{ESI}^{+}\right) \mathrm{m} / \mathrm{z} 332.1\left([\mathrm{M}+\mathrm{Na}]^{+}\right) ;\left(\mathrm{ESI}^{-}\right) \mathrm{m} / \mathrm{z} 308.1\left([\mathrm{M}-\mathrm{H}]^{-}\right)$ IR $\left(\mathrm{cm}^{-1}\right)$ v 3327, 2974, 2930, 2879, 2831, 1651, 1519, 1440, $1393,1365,1353,1325,1303,1255,1230,1203,1173,1150$, 1108, 1080, 1062, 997, 978, 925, 847, 758, 726

\section{(18-crown-6)K[Co"'(R,R-L $\left.\left.{ }^{1}\right)_{2}\right](1 \mathrm{a})$}

${ }_{50} \mathrm{KH}(0.08 \mathrm{~g}, 1.34 \mathrm{mmol})$ and $\mathrm{H}_{2}\left(R, R-\mathrm{L}^{1}\right)(0.250 \mathrm{~g}, 0.67 \mathrm{mmol})$ were dissolved in dry THF (15 ml) under argon and stirred for $1 \mathrm{~h}$. A solution of $\mathrm{CoCl}_{2}(0.045 \mathrm{~g}, 0.34 \mathrm{mmol})$ in dry MeCN (15 $\mathrm{ml}$ ) was added and stirred under argon overnight. The solution was left for oxidation in air and then filtered. The 55 precipitate was redissolved in MeCN, solid 18-crown-6 $(0.09 \mathrm{~g}, 0.34 \mathrm{mmol})$ was added and the solution was stirred overnight. The reaction mixture was concentrated and $\mathrm{Et}_{2} \mathrm{O}$ was added to give green crystals. Yield $0.122 \mathrm{~g}, 0.14 \mathrm{~g}(38 \%)$. (In another experiment, single crystals of $1 \mathbf{a} \cdot \mathrm{H}_{2} \mathrm{O} \cdot \mathrm{CH}_{3} \mathrm{CN}$ were 60 obtained by slow diffusion of diethyl ether into a solution of the complex in acetonitrile in air over weeks.)

Elemental analysis found (calculated for $\mathrm{C}_{58} \mathrm{H}_{66} \mathrm{CoKN}_{6} \mathrm{O}_{10}$ ) \%: C 62.57 (63.03), H 6.11 (6.02), N 7.79 (7.60).

${ }_{65}{ }^{1} \mathrm{H}$ NMR (300 MHz, 298K, $\left.\mathrm{CD}_{3} \mathrm{CN}\right) \delta^{\mathrm{H}} 8.26\left(2 \mathrm{H}, \mathrm{t}, \mathrm{J}_{\mathrm{HH}}=8 \mathrm{~Hz}, \mathrm{Ar}-\right.$ $\mathrm{H}), 7.90\left(4 \mathrm{H}, \mathrm{d}, \mathrm{J}_{\mathrm{HH}}=8 \mathrm{~Hz}, \mathrm{Ar}-\mathrm{H}\right), 6.87(2 \mathrm{OH}, \mathrm{m}, \mathrm{Ar}-\mathrm{H}), 3.57$ $(24 \mathrm{H}, \mathrm{s}, \mathrm{C}-\mathrm{H}$, crown $), 2.68\left(4 \mathrm{H}, \mathrm{q}, \mathrm{J}_{\mathrm{HH}}=7 \mathrm{~Hz}, \mathrm{C}-\mathrm{H}\right), 1.02(12 \mathrm{H}, \mathrm{d}$, $\left.\mathrm{J}_{\mathrm{HH}}=7 \mathrm{~Hz}, \mathrm{CH}_{3}\right)$

${ }^{13} \mathrm{C}$ NMR (100 MHz, $\left.298 \mathrm{~K}, \mathrm{MeOD}\right) \delta_{\mathrm{c}} 169.0$ (C=0), 160.0, $70144.4,141.8$ (pyr), 129.5, 128.6, 127.1, 125.2 (ph), 71.3 (crown) $57.4(\mathrm{C}-\mathrm{H}), 20.8\left(\mathrm{CH}_{3}\right)$

MS (ESI $\left.{ }^{+}\right) \mathrm{m} / \mathrm{z} 303.0\left(\left[(18-\text { crown-6)K }]^{+}\right) ; \quad\left(\mathrm{ESI}^{-}\right) \mathrm{m} / \mathrm{z} 801.4\right.$ $\left(\left[\mathrm{M}\left(\mathrm{L}^{1}\right)_{2}\right]^{-}\right)$

IR $\left(\mathrm{cm}^{-1}\right) \vee 2888,1571,1492,1452,1102,956,835,775,698$, 75685 .

\section{(18-crown-6)K[Fe"'(R,R-L $\left.\left.{ }^{1}\right)_{2}\right](2)$}

Compound was prepared analogously to 1 using $\mathrm{FeCl}_{2}(0.043$ $\mathrm{g}, 0.34 \mathrm{mmol})$. Red crystalline solid obtained. Yield $0.11 \mathrm{~g}$ (29\%).

${ }_{80}$ Elemental analysis found (calculated for $\mathrm{C}_{58} \mathrm{H}_{66} \mathrm{FeKN}_{6} \mathrm{O}_{10}$ $\left.\cdot 2 \mathrm{H}_{2} \mathrm{O}\right) \%$ : C 61.20 (61.20), H 5.83 (6.20), N 7.34 (7.38).

MS (ESI $\left.{ }^{+}\right) \mathrm{m} / \mathrm{z} 303.0\left(\left[(18 \text {-crown-6)K }]^{+}\right) ;\left(\mathrm{ESI}^{-}\right) \mathrm{m} / \mathrm{z} 798.5\right.$ $\left(\left[\mathrm{M}\left(\mathrm{L}^{1}\right)_{2}\right]^{-}\right)$

IR $\left(\mathrm{cm}^{-1}\right) \vee 3059,2901,1565,1492,1452,1386,1352,1324$, ${ }_{85} 1287,1251,12161197,1101,1034,1013,953,923,864,838$, $773,746,735,699,690$

\section{$\mathrm{K}\left[\mathrm{CO}^{\prime \prime \prime \prime}\left(S, S-\mathrm{L}^{2}\right)\right] \cdot 3 \mathrm{H}_{2} \mathrm{O}(3)$}

Sodium hydride $(0.038 \mathrm{~g}, 0.96 \mathrm{mmol})$ and $\mathrm{H}_{2}\left(S, S-L^{2}\right)(0.100 \mathrm{~g}$, $0.32 \mathrm{mmol})$ were suspended in dry THF $(10 \mathrm{ml})$ under argon 90 and stirred under partial vacuum for $15 \mathrm{~min}$. Cobalt(II) chloride $(0.021 \mathrm{~g}, 0.16 \mathrm{mmol})$ in dry MeCN $(10 \mathrm{ml})$ was added dropwise and the mixture was stirred overnight under argon. The mixture was opened to air and stirred for $24 \mathrm{~h}$. The solids were removed by filtration and a few drops of water were 95 added to the filtrate. Green crystalline product was obtained upon a slow addition of $\mathrm{Et}_{2} \mathrm{O}$. Yield $0.077 \mathrm{~g}$ (62.8\%).

Elemental Analysis found (Calculated for $\mathrm{C}_{30} \mathrm{H}_{48} \mathrm{CoKN}_{6} \mathrm{O}_{11}$ ) \%: C 47.06 (46.99), H 6.18 (6.31), N 10.80 (10.96)

${ }^{1} \mathrm{H}$ NMR $\left(400 \mathrm{MHz}, 298 \mathrm{~K}, \mathrm{CD}_{3} \mathrm{CN}\right) \delta_{\mathrm{H}} 0.89\left(6 \mathrm{H}, \mathrm{d},{ }^{2} \mathrm{~J}_{\mathrm{HH}}=6.7 \mathrm{~Hz}\right.$, $\left.100-\mathrm{CH}_{3}\right), 1.49(2 \mathrm{H}, \mathrm{s}$ broad, $\mathrm{CH}), 2.98\left(6 \mathrm{H}, \mathrm{s},-\mathrm{OCH}_{3}\right), 3.11(2 \mathrm{H}$, $\left.\mathrm{dd},{ }^{2} \mathrm{~J}_{\mathrm{HH}}=9.2 \mathrm{~Hz},{ }^{3} \mathrm{~J}_{\mathrm{HH}}=3.5 \mathrm{~Hz}, \mathrm{CH}_{2}\right), 3.67\left(2 \mathrm{H}, \mathrm{t}^{2}{ }^{2} \mathrm{JHH}_{\mathrm{H}}=9.1 \mathrm{~Hz}\right.$, $\left.\mathrm{CH}_{2}\right), 7.93\left(2 \mathrm{H}, \mathrm{d},{ }^{3} \mathrm{~J}_{\mathrm{HH}}=7.7 \mathrm{~Hz}, \mathrm{pyr}\right), 8.28\left(1 \mathrm{H}, \mathrm{t},{ }^{3} \mathrm{~J}_{\mathrm{HH}}=7.7 \mathrm{~Hz}\right.$, pyr)

${ }^{13} \mathrm{C}$ NMR $\left(100 \mathrm{MHz}, 298 \mathrm{~K}, \mathrm{CD}_{3} \mathrm{CN}\right) \delta_{\mathrm{C}} 17.6\left(-\mathrm{CH}_{3}\right), 52.5(\mathrm{CH})$, $10558.3\left(-\mathrm{OCH}_{3}\right), 77.3\left(\mathrm{CH}_{2}\right), 123.6,140.7,159.1$ (pyr), 167.8 (C=O)

MS (ESI') m/z $673.3\left([M-K]^{-}\right) ; M S\left(E S I^{+}\right) \mathrm{m} / \mathrm{z} 751.1\left([\mathrm{M}+\mathrm{K}]^{+}\right)$, $713.1\left([\mathrm{M}+\mathrm{H}]^{+}\right)$

IR $\left(\mathrm{cm}^{-1}\right) \vee 3510,3039,2974,2936,2824,1571,1449,1425$, $1101397,1387,1357,1336,1317,1227,1198,1146,1086,976$, $943,929,893,866,847,778,685$

(TTF) $\left[\mathrm{Co}^{\prime \prime \prime}\left(R, R-\mathrm{L}^{1}\right)_{2}\right](4)$ 
(18-crown-6)K[Co $\left.{ }^{\prime \prime \prime}\left(R, R-\mathrm{L}^{1}\right)_{2}\right]$ (1) (20 mg) was dissolved in dry THF $(25 \mathrm{ml})$. Solid TTF $(5 \mathrm{mg})$ was placed in the anode chamber of an electrocrystallisation cell, then the cell was carefully filled with the solution of the counterion. The cell 5 was fitted with platinum electrodes and sealed. A constant current of $1 \mu \mathrm{A}$ was applied. After two weeks dark crystals suitable for X-ray diffraction and conductivity measurement were harvested.

IR $\left(\mathrm{cm}^{-1}\right)$ v $1577,1475,1451,1362,1330,1291,1226,1093$, $101077,1063,822,756,697,682$

\section{(TTF) $\left[\mathrm{Fe} \mathrm{e}^{\mathrm{II \prime}}\left(R, R-\mathrm{L}^{1}\right)_{2}\right]$}

Obtained analogously to 4 using (18-crown-6) K[Fe $\left.\mathrm{Fe}^{\prime \prime \prime}\left(R, R-\mathrm{L}^{1}\right)_{2}\right]$ (2) $(20 \mathrm{mg})$. Dark microcrystalline solid collected. No crystals of quality suitable for X-ray diffraction or conductivity 15 measurements were found.

IR $\left(\mathrm{cm}^{-1}\right)$ v 1564, 1491, 1473, 1451, 1383, 1361, 1324, 1288, 1274, 1211, 1195, 1151, 1077, 1054, 1032, 1010, 947, 911, $868,842,824,772,756,741.9,786$

\section{(TTF) $\left[\mathrm{Co}^{\prime \prime \prime}\left(S, S-\mathrm{L}^{2}\right)_{2}\right] \cdot$ EtOAC (5)}

$20 \mathrm{TTF}_{3}\left(\mathrm{BF}_{4}\right)_{2}(10 \mathrm{mg}, 12.9 \mu \mathrm{mol})$ was dissolved in a minimal amount of acetonitrile $(\sim 1 \mathrm{ml}) . \mathrm{K}\left[\mathrm{Co}^{\prime \prime \prime}\left(S, S-\mathrm{L}^{2}\right)_{2}\right] \cdot 3 \mathrm{H}_{2} \mathrm{O}(19.5$ $\mathrm{mg}, 25.4 \mu \mathrm{mol})$ was dissolved in a minimal amount of acetonitrile $(\sim 1 \mathrm{ml})$. The solutions were mixed slowly and filtered through a cotton wool plug. A dark crystalline solid

25 was obtained by a slow diffusions of ethyl acetate into the solution. Single crystals suitable for X-ray diffraction and conductivity measurement were harvested.

MS $\left(\mathrm{ESI}^{+}\right) \mathrm{m} / \mathrm{z} 203.9\left([\mathrm{TTF}]^{+}\right)$; $\mathrm{MS}\left(\mathrm{ESI}^{-}\right) \mathrm{m} / \mathrm{z} 673.3\left(\left[\mathrm{Co}^{\mathrm{III}}\left(\mathrm{L}^{2}\right)_{2}\right]^{-}\right)$ IR $\left(\mathrm{cm}^{-1}\right)$ v 1716, 1571, 1506, 1574, 1452, 1394, 1374, 1357, 30 1347, 1312, 1294, 1272, 1231, 1193 1143, 1102, 1087, 1071, $1039,965,930,900,866,845,823.8,778,732,682$

\section{Acknowledgements}

We thank the EPSRC for funding and the EPSRC National Crystallography Service and Oxford diffraction for collecting 35 the crystal data. The Oxford Diffraction Gemini XRD system was obtained through the Science City Advanced Materials project: Creating and Characterising Next Generation Advanced Materials, with support from Advantage West Midlands (AWM) and part funded by the European Regional 40 Development Fund (ERDF).

\section{Notes and references}

${ }^{a}$ Department of Chemistry, University of Warwick, Coventry, UK, CV4 7AL; E-mail: peter.scott@warwick.ac.uk; Fax: +44 (0)24 7657 2710; Tel: $+44(0) 2476523238$

${ }_{45}{ }^{b}$ Department of Chemistry, University of Surrey, Guildford, Surrey, UK, GU2 $7 X H$

† Electronic Supplementary Information (ESI) available: [details of any supplementary information available should be included here]. See DOI: 10.1039/b000000x/

$50 \ddagger$ Recrystallisation from other solvent mixtures resulted in microcrystalline precipitates of insufficient quality for single crystal X-ray diffraction measurements.

$\S$ Cyclic voltammogram of the neutral TTF was recorded in $0.1 \mathrm{mM}$ solution of $\mathrm{NaPF}_{6}$.
1. G. L. J. A. Rikken, J. Folling and P. Wyder, Phys. Rev. Lett., 2001, 87, 236602.

2. V. Krstic and G. L. J. A. Rikken, Chem. Phys. Lett., 2002, 364, 51-56.

3. N. P. Chmel, S. E. Howson, L. E. N. Allan, J. Barker, G. J. Clarkson, S. S.

$60 \quad$ Turner and P. Scott, Dalton Transactions, 2010, 39, 29192927.

4. N. Avarvari and J. D. Wallis, J. Mater. Chem., 2009, 19, 4061-4076.

5. S. E. Howson, L. E. N. Allan, N. P. Chmel, G. J. Clarkson, R. van Gorkum and P. Scott, Chem Commun, 2009, 1727-1729.

65 6. J. Barton, Science, 1986, 233, 727-734.

7. H. Tsukube and S. Shinoda, Chem. Rev., 2002, 102, 2389-2404.

8. P. Y. Toullec and V. Michelet, Curr. Org. Chem., 2010, 14, 1245-1253.

9. Y. N. Belokon, Pure Appl. Chem., 1992, 64, 1917-1924.

10. H. C. Aspinall, Chem. Rev., 2002, 102, 1807-1850.

70 11. C. A. Caputo and N. D. Jones, Dalton Trans., 2007, 4627-4640.

12. F. Favarger, C. Goujon-Ginglinger, D. Monchaud and J. Lacour, J. Org. Chem., 2004, 69, 8521-8524.

13. J. Lacour, C. Ginglinger, C. Grivet and G. Bernardinelli, Angew. Chem. Int. Ed., 1997, 36, 608-610.

75 14. R. C. Burrows and J. C. Bailar, J. Am. Chem. Soc., 1966, 88, 41504156.

15. Y. Belokon', V. Maleev, I. Mal'fanov, T. Savel'eva, N. Ikonnikov, A Bulychev, D. Usanov, D. Kataev and M. North, Russ. Chem. Bull., 2006, 55, 821-827.

80 16. M. Nonoyama, Inorg. Chim. Acta, 1974, 10, 59-63.

17. F. A. Chavez, M. M. Olmstead and P. K. Mascharak, Inorg. Chem. 1996, 35, 1410-1412.

18. F. A. Chavez, C. V. Nguyen, M. M. Olmstead and P. K. Mascharak, Inorg. Chem., 1996, 35, 6282-6291.

85 19. A. N. Dwyer, M. C. Grossel and P. N. Horton, Supramol. Chem., 2004, 16, $405-410$.

20. M. Ray, D. Ghosh, Z. Shirin and R. Mukherjee, Inorg. Chem., 1997, 36, 3568-3572.

21. A. Mishra, A. Ali, S. Upreti, M. S. Whittingham and R. Gupta, Inorg. Chem., 2009, 48, 5234-5243.

22. J. L. Bricks, G. Reck, K. Rurack, B. Schulz and M. Spieles, Supramol. Chem., 2003, 15, 189 - 197.

23. D. S. Marlin, M. M. Olmstead and P. K. Mascharak, Inorg. Chem. 1999, 38, 3258-3260.

95 24. D. A. Clemente and A. Marzotto, J. Mater. Chem., 1996, 6, 941-946.

25. F. Wudl, J. Am. Chem. Soc., 1975, 97, 1962-1963.

26. F. Wudl, G. M. Smith and E. J. Hufnagel, J. Chem. Soc. D Chem. Comm., 1970, 1453-1454.

27. J. B. Torrance, B. A. Scott, B. Welber, F. B. Kaufman and P. E. Seiden,

$100 \quad$ Phys. Rev. B, 1979, 19, 730

28. C. Baehtz, H. Ehrenberg and H. Fuess, Phys. Chem. Chem. Phys., 2000, 2, 5764-5770

29. J. Wang, in Analytical Electrochemistry (Third Edition), Wiley-VCH, Hoboken, 2006, pp. 29-66.

105 30. R. Carlier, A. Tallec, P. Frere, M. Salle, M. Jubault, A. Gorgues and J. Cousseau, Synth. Met., 1993, 56, 2359-2363.

31. Y. Tatewaki, T. Hatanaka, R. Tsunashima, T. Nakamura, M. Kimura and H. Shirai, Chem. Asian J., 2009, 4, 1474-1479.

32. M. Iyoda, M. Hasegawa and H. Enozawa, Chem. Lett., 2007, 36, 110 1402-1407. 
33. C. E. Hughes, S. Hamad, K. D. M. Harris, C. R. A. Catlow and P. C. Griffiths, Faraday Discuss., 2007, 136, 71-89.

34. J. H. So and P. Boudjouk, Inorg. Chem., 1990, 29, 1592-1593.

35. J. P. Leonard, P. Jensen, T. McCabe, J. E. O'Brien, R. D. Peacock, P. E. Kruger and T. Gunnlaugsson, J. Am. Chem. Soc., 2007, 129, 10986-10987.

36. G. M. Sheldrick, Acta Crystallogr., Sect. A, 1990, 46, 467-473.

37. G. M. Sheldrick, Acta Crystallogr., Sect. A, 2008, 64, 112-122. 